\title{
ANA ACESKA \\ Transnational Experts, Rooted Careers. Migrant Professionals from Macedonia in Germany
}

\begin{abstract}
This article is based on a study of migrant professionals from Macedonia who are now in Germany. It aims to assess how migrants who practise professions relate to their identities as experts who can sustain (or at least have the opportunity to sustain) relationships linking their places and societies of origin and the places where they have settled, and who can use these links to assist their careers. The results show a particular pattern: simultaneously, these migrant professionals promote their expertise as 'transnational', but aim to have careers that are rooted in one place.
\end{abstract}

Ana Aceska is a post-doctoral researcher at the Institute for Urban and Regional Sociology at the Humboldt University, Berlin.

\section{Introduction}

Understanding the ways and contexts in which migrants sustain relationships between their countries of origin and the countries in which they settle has been the central question in migration studies for decades. However, scholars rarely discuss these relationships in connection with the migrants' work and career plans. This article looks at one particular group-migrant professionals from Macedonia who are now in Germany - and seeks to assess how its members perceive their identities as professionals who, in the context of pursuing their careers, sustain (or at least have the opportunity to sustain) relationships linking the places and societies they come from and those where they currently practise.

Following the lead of Maier, I use the term 'migrant professionals' to refer to a well-educated group which differs from the migrants commonly referred to as 'skilled' or even 'highly skilled' in one crucial aspect: its members can work as full professionals after their migration, and their skills and formal education are accepted in the country they have adopted. ${ }^{1}$ This allows them to maintain relatively high status and gives them access to preferential treatment in many

${ }^{1}$ Lars Maier, ed, Migrant Professionals in the City. Local Encounters, Identities, Inequalities, New York and London 2015. 
areas, such as easier access to the job market and to privileges linked with their careers. This difference is important, as not all highly skilled migrants are able to secure a professional position commensurate with their qualifications - either because the host countries do not accept the formal qualifications awarded in their countries of origin, or because, for lack of places, these migrants have had to accept jobs less skilled than the ones they used to have. ${ }^{2}$ The term 'migrant professionals', as Maier argues, underlines the importance of work and career in the decisions of this particular group to migrate, and this further differentiates its members from those highly skilled migrants who have moved with the sole aim of enhancing their quality of life. Other terms have been used in the literature to refer to the same group. For example, Fechter and Walsh use the terms 'mobile professionals' or 'privileged migrants' to refer to European or North American nationals who migrate to other countries, including former colonies, for work-related reasons. ${ }^{3}$ However, this article employs the term 'migrant professionals', as it most accurately describes the group in focus.

In the article, I aim to find out how migrant professionals who have moved from Macedonia to Germany over the last decade relate to their (new) identities as professionals who, in the context of their careers, can sustain relationships linking the places and societies they came from and the German milieux they are now in. This is important to explore, as, once the migrants have settled, not only the new country but also the new workplace offers a context in which identities are to be constructed. However, the negotiation of new identities in this context is by no means simple or straightforward for the migrants: they are professionals who have come to the EU from a country that is at the margins of Europe-from the EU's shrinking 'immediate outside'. ${ }^{4}$ While the EU is just next-door, it offers many more professional opportunities to them than their country of origin. Moreover, for these professionals the decision to migrate to Germany might be the central event of their careers and personal lives, and it is likely that in most cases it is considered an advantage on their curriculum vitae. All the same, they may well not have had all the privileges enjoyed by professional migrants moving within the EU: the process of getting a visa may have taken longer, and they may have been subjected to a larger and more complex administration process to have their qualifications accepted, as the EU countries can employ professionals from non-EU countries only if the institu-

${ }^{2}$ Lars Maier, Introduction. Local Lives, Work and Social Identities of Migrant Professionals in the City, in: Maier, ed, Migrant Professionals, 1-13.

${ }^{3}$ Anne-Meike Fechter / Katie Walsh, Examining 'Expatriate' Continuities. Postcolonial Approaches to Mobile Professionals, Journal of Ethnic and Migration Studies 36, No. 8 (2010), 1197-1210.

4 Stef Jansen, After the Red Passport. Towards an Anthropology of the Everyday Geopolitics of Entrapment in the EU's 'Immediate Outside', Journal of the Royal Anthropological Institute 15, No. 4 (2009), 815-832, 815. 
tion ready to employ them can verify that there is no EU citizen qualified to take the position in question.

Over the last few decades, scholars have analysed many aspects of identityrelated experiences and orientations of migrants in relation to their countries of origin and destinations. As Faist points out, older notions of 'assimilation', used from the 1920s up to the 1960s, influenced perceptions of migrants in one particular way: imposing an assumption that they had to orient themselves to certain roles or to the related behavioural expectations attached to those roles that the majority held for migrants. ${ }^{5}$ As he argues further, basing his conclusions on the work of Alba and Nee, more recent assimilation theories, such as 'new assimilationism' no longer take it for granted that there is a societal core to which migrants unquestioningly orient themselves. ${ }^{6}$

Many scholars have, quite rightly, criticised both assimilation and newassimilation theories, and have adopted arguments from constructivist theories of identity-formation, which claim that social identities are not static or given, but are constantly changing and ever-in-the-making: social identities have no pure form, but are hybrid and mixed. ${ }^{7}$ Transnationality can accordingly be defined as a process in which migrants sustain relationships that link the places and societies they come from and the places where they have settled. ${ }^{8}$ Today we know that migrants develop orientations that link them with others who do not reside in their immediate living environments, but live elsewhere, maybe in other countries. ${ }^{9}$ In their new lives, migrants depend on multiple interconnections maintained across international borders; and they participate in different

5 Thomas Faist, Diversity. A New Mode of Incorporation?, Ethnic and Racial Studies 32, No. 1 (2009), 171-190, referring to Milton Gordon, Assimilation in American Life. The Role of Race, Religion, and National Origins, New York 1964.

${ }^{6}$ Richard Alba/Viktor Nee, Remaking the American Mainstream. Assimilation and Contemporary Immigration, Cambridge/MA 2003.

7 For more on constructivist theories of identity-formation, see Fredrik Barth, Ethnic Groups and Their Boundaries, Boston 1969; Fredrik Barth, Boundaries and Connections, in: Anthony P. Cohen, ed, Signifying Identities. Anthropological Perspectives on Boundaries and Contested Values, London 2000, 17-37; Rogers Brubaker / Frederick Cooper, Beyond 'Identity', Theory and Society 29, No. 1 (2000), 1-47; Karen A. Cerulo, Identity Construction. New Issues, New Directions, Annual Review of Sociology 23 (1997), 385-409; Anthony P. Cohen, The Symbolic Construction of Community, London and New York 1985; Philip Gleason, Identifying Identity. A Semantic History, Journal of American History 69, No. 4 (1983), 910-931; Donald L. Horowitz, Ethnic Groups in Conflict, Berkeley 1985; Richard Jenkins, Social Identity, London and New York 1996; Richard Jenkins, Rethinking Ethnicity. Arguments and Explorations, London 1997.

8 Nina Glick-Schiller/Linda Basch / Cristina Szanton Blanc, From Immigrant to Transmigrant. Theorizing Transnational Migration, Anthropological Quarterly 68, No. 1 (1995), 48-64; quoted in Tuna Tasan-Kok et al., Towards Hyper-Diversified European Cities. A Critical Literature Review, Utrecht 2013, 28.

9 Steven Vertovec, Towards Post-Multiculturalism? Changing Communities, Conditions and Contexts of Diversity, International Social Science Journal 61, No. 199 (2010), 83-95. 
spheres of life simultaneously - spheres that encompass not only their places of origin and destination but places elsewhere. Thus, as Phillips argues, we can no longer assume that these migrants set out on a simple trajectory of assimilation into the nation state in which they have come to live. ${ }^{10}$

What is more, many studies have shown that identity-related experiences and orientations are important in a range of ways in migrant professionals' lives. Scholars have focused on understanding aspects of their various identities in a postcolonial context, ${ }^{11}$ as well as in situations where they have relocated within the EU for work reasons. ${ }^{12}$ For example, Lan looks at migration of highly skilled people from the West to Asia and explores how these particular migrants exert agency to negotiate their positions as non-citizens, privileged others, and professional workers. She proposes the term 'flexible cultural capital conversion' to describe how English-speaking Westerners convert their native-language skills, as a form of global linguistic capital, into economic, social and symbolic capitals. ${ }^{13}$ She argues, moreover, that their privileged positions are mediated (and constrained) by their class, nationality, race/ethnicity, and gender, which can all place white foreigners in privileged and segregated jobs.

Another example is to be found in the work of Leonard on the identity dimension of 'whiteness' and gender in the everyday lives of white expatriates in Hong Kong. ${ }^{14}$ She argues that whiteness is a relevant identity dimension for these expatriates in their everyday lives; and one of the many reasons for this is that Hong Kong is a place where race matters. Leonard argues that the dynamic social and political context of Hong Kong is very important, and is mediated through expatriate contexts in many ways.

Particularly telling are the studies of Maier and Andreotti, Le Galès, and Moreno-Fuentes, which show how important locality is in the life of migrants. ${ }^{15}$ In an introduction to a collection of essays, Mayer criticises the perception that migrant professionals are a homogenous group defined by their embed-

10 Deborah Phillips, Ethnic and Racial Segregation. A Critical Perspective, Geography Compass 1, No. 5 (2007), 1138-1159; quoted in Tasan-Kok et al., Towards Hyper-Diversified European Cities, 28.

11 Pei-Chia Lan, White Privilege, Language Capital and Cultural Ghettoisation. Western High-Skilled Migrants in Taiwan, Journal of Ethnic and Migration Studies 37, No. 10 (2011), 16691693; Pauline Leonard, Work, Identity and Change? Post-Colonial Encounters in Hong Kong, Journal of Ethnic and Migration Studies 36, No. 8 (2010), 1247-1263; Fechter / Walsh, Examining 'Expatriate' Continuities.

${ }^{12}$ Adrian Favell, Eurostars and Eurocities. Free Movement and Mobility in an Integrating Europe, Oxford 2008.

13 Lan, White Privilege, Language Capital and Cultural Ghettoisation, 1669.

14 Leonard, Work, Identity and Change?

15 Maier, Introduction, 1-13; Alberta Andreotti / Patrick Le Galès / Francisco Javier MorenoFuentes, Globalised Minds, Roots in the City. Urban Upper-Middle Classes in Europe, New York 2015. 
dedness in transnational networks and disconnected from locality. Presenting empirical evidence about professionals and managers in several European cities, Andreotti, Le Galès, and Moreno-Fuentes ask how, and to what extent, the European upper middle class has become transnational. Their answer is: less than we might assume. They argue that, though these groups are becoming more cosmopolitan, they are, at the same time, becoming more locally rooted, and in many specific ways.

This paper aims to contribute to these debates by trying to understand how the professionals who have migrated from Macedonia to Germany over the last decade relate to their status as professionals able to draw on contacts and resources from at least two places: their original homes and their new places of settlement. The main questions are whether, and how, they negotiate their positions as 'transnationals' to assist their work and career, and how they define their distinct identities and differentiate between themselves and others in the context in which they find themselves.

The conclusions of the research reveal several patterns. First, the data show that these migrant professionals regard their status as 'transnationals' as something that can be converted into social, economic, and cultural capital to assist their careers. They mobilise their cross-border ties, networks and connections with their colleagues in Macedonia to achieve better or, in most cases, 'unique' positions in their workplaces in Germany. More importantly, they do this not only to achieve better or unique profiles at work, but also to secure more stable positions in the labour market, most often in the institutions where they are currently working. And this is because they want to remain or become rooted in the places they have come to. Thus, simultaneously, they promote their status as 'transnational experts', but aim to have careers that are rooted in one place. This pattern is visible in boundary-work processes too: in the stories these professionals tell about who they are, their main boundary-work is not between themselves and the other migrant professionals from Macedonia or elsewhere - not even between themselves and less skilled migrants, as might be assumed. They compare their position primarily with their German colleagues at work and in their surroundings, who have more straightforward, rooted and linear careers in their own home country (Germany) but have no transnational experiences of the kind the migrants from Macedonia have had.

\section{Methodology}

The empirical material forming the basis of this piece of research consists of narrative interviews with twelve migrant professionals from Macedonia who have settled in Germany - ten of ethnic Macedonian origin and two of ethnic Albanian origin. The interviews were conducted over a period of seven months 
in the academic year 2012/13. As concerns the composition of the group of respondents, it is worth noting that seven of them were men and five were women; six of the total number were medical doctors by profession or pursued a career in medicine-related research; three were IT experts or computer scientists; two were scholars in economics or social science; and one was a businessman. Six of the informants were in their 30s at the time of the interview; four in their 40s; and two in their 50s. All of them had BA degrees (4-6 year study programmes) from the Macedonian state university, Ss. Cyril and Methodius; six of them had MA degrees; and three had PhDs; while nine of the total number had gained at least one higher degree or done some kind of training in Germany or another EU country. The length of their residence in Germany ranged from three to eight years at the time of the interview; and nine of them had previously resided in some EU country to study or to gain work-related qualifications. Ten held a work visa, and two had German passports (through marriages to German citizens).

The interviews were semi-structured, discussion focusing on six main topics. In the first section, I asked questions to assess what the interviewees felt had changed most in their work and careers since they had migrated to Germany. In the next section, I asked the subjects how they were developing their careers in their new workplaces and what their career strategies were. The subquestions in this section explored whether (and how) they were working on projects in any way related to Macedonia. In the third section I asked whether they kept up ties, networks, and connections with their former colleagues in Macedonia, and in what way. The questions in this section were directed at finding out how they mobilised networks with former Macedonian colleagues for the purposes of their present work. The fourth section enquired into how these migrant professionals saw themselves in their new situations in Germany and delved into what future plans they might have in terms of work and career. The fifth and the sixth sections were devoted to questions of 'place-making', the results of which will be published in an additional paper.

I encountered difficulties in recruiting the interviewees, mainly because the target group is a relatively narrow one and it was not easy to locate those who belonged to it, but also because the potential interviewees were very busy professionals and in most cases had no time to meet me. The interviews were conducted at different locations. Those with the seven respondents residing in Berlin took place either in their homes or in their offices in the city. Three of the interviews were conducted through Skype, and two took place in Skopje because both the respondents and I happened to be there at the same time. All the interviews were conducted in the Macedonian language. They lasted from one to three hours and were tape-recorded and fully transcribed. The analyses of the interviews took into account internal differences amongst the respondents, 
such as gender, ethnicity, profession, and marital status; but as the sample was too small to find meaningful patterns connected with these categories, I will mainly discuss analyses related to the research questions this article sets out to address.

The issue of migrant professionals who have translocated from Macedonia to Germany has some peculiarities of its own. The movement of professionals across boundaries is not a new phenomenon in the world, but Macedonia-one of the poorest countries in Europe with growing political, economic and social problems - presents a particular case. Recently the exodus of professionals has reached extreme dimensions. As the Macedonian state has no systematic record of who has left the country, and the census has been postponed open-endedly, we have to resort to the frequent media reports about this problem to provide some context. These substantiate that a significant part of the population has left the country in the last ten years and that many of the leavers are highly skilled professionals who have emigrated in order to continue their careers abroad. In research conducted in 2013, for example, the health groups concluded that 63 per cent of the doctors in Macedonia who want to change posts aim to continue their careers in a foreign country, while 50 per cent of the country's medical students want to live and work abroad. ${ }^{16}$ The Institute for Economics has also published research indicating that most of those who aim to migrate are engineers and doctors. ${ }^{17}$ According to various media reports, a number of excellent students have publicly declared that they want to leave Macedonia as soon as they get the opportunity. ${ }^{18}$ Meanwhile, the domestic market has been adapting to the new situation: schools for German as a second language are already offering special extra-intensive courses for doctors, and various consultancy agencies offer services and advice on how to emigrate.

Germany, too, is in some ways a particular case. Faist informs us that, while migrants had come there from only about a dozen countries in the 1960s, in 2004 the records showed that only around 50 per cent of migrants came from the ten main countries of origin (including Turkey, Poland, Russia, the US, and the states of the former Yugoslavian territory), while the other 50 per cent came from over 100 different countries outside that orbit. ${ }^{19}$ Faist explains that

${ }^{16}$ Mihajlo Vidimliski, Istrazhuvanje na Heltgruper. Se pogolem broj na doktori razmisluvaat da ja napushtat drzhavata, 24vesti.mk, 19 April 2014, http://24vesti.mk/istrazhuvanje-naheltgruper-se-pogolem-broj-na-doktori-razmisluvaat-da-ja-napushtat-drzhavata. All internet references were accessed on 4 February 2016.

17 Najmnogu se otseluvaat inzheneri i doktori. Koj kje raboti vo Makedonija?, kapital. mk, 7 June 2012, http://www.kapital.mk/mk/makedonija/84951/najmnogu_se_otseluvaat_ inzheneri_i_doktori_koj_kje_raboti_vo_makedonija_.aspx.

18 See for example Ivana Mitkovska, ,Mladite mozotsi' masovno ja napushtat Makedonij, Brif.mk, 13 November 2013, http://brif.mk/?p=103793.

${ }_{19}$ Faist, Diversity. A New Mode of Incorporation?, 171. 
the composition of the migrant population has changed too: the proportion of newer, smaller groups in relation to older, larger groups of migrants has grown. ${ }^{20}$ He gives the example of the city of Hamburg, where, in the years between 2003 and 2006, not only has the proportion of the population who are of Turkish descent declined and the proportion of migrants from Poland increased, but there has been a sudden and significant growth in numbers of groups that were hitherto not particularly strongly represented, such as migrants from Ukraine, the Philippines, Togo, Vietnam and India. ${ }^{21}$ Scholars need to explore how these migrants feel about their identity and transnationality in this context. This is one of the crucial questions that will help us determine how important specificities of place may be.

\section{Transnationality As Capital}

To understand the ways in which migrants with professional training convert their transnational ties, networks and experiences into capital, we require a more precise definition of what transnationalism means. Transnationalism can be best defined as the process by which immigrants forge and sustain relationships that link their societies of origin and the milieux where they have since settled. ${ }^{22}$ This is a process in which contemporary migrants engage in different and multiple ways simultaneously in both their country of origin and in their country of destination; and, by doing so, they come to identify themselves with places, ethnic and religious communities, nationalities, families, and friendships across national borders. Transnationalism is an even larger process than this, however: for not only are the places of origin and destination important in the lives of migrants, but also other places, such as those where family or friends live, or those that are important in their professions or for personal and other reasons. These are significant transnational social spaces and relationships, as Faist argues, since not only geographical mobility, but also continued contacts between migrants and others have importance. ${ }^{23} \mathrm{~A}$ variety of these continued ties exists within families, or religious or ethnic communities, but the focus of the analyses in this paper is on those that exist through professional groups.

The interviews quoted below show how these migrants discuss their transnational status as something that can be converted into social, economic, and cultural capital for their careers, and how they mobilise their cross-border ties,

20 Faist, Diversity. A New Mode of Incorporation?, 172.

21 Statistikamt Nord, Statistisches Jahrbuch Hamburg 2007/2008, Hamburg, quoted in Faist, Diversity. A New Mode of Incorporation?, 180.

22 Glick-Schiller / Basch / Szanton Blanc, From Immigrant to Transmigrant.

23 Faist, Diversity. A New Mode of Incorporation?; cf. Thomas Faist, Transnationalization in International Migration. Implications for the Study of Citizenship and Culture, Ethnic and Racial Studies 23, No. 2 (2000), 189-222. 
networks and connections with colleagues in Macedonia in order to attain better positions in their workplaces in Germany. Beaverstock has noticed a similar pattern among British expatriates living in New York. ${ }^{24}$ In his research, he shows how these individuals have connected their local knowledge of New York with their colleagues' local knowledge in London. Thus, he argues, the central principle of these expatriates' transnationalism has been their cross-border organisational ties and connections with working colleagues in their country of origin, as well as in other financial centres.

However, in the context of this paper, it is more important to understand aspects of what happens to the value of the specific knowledge or skill in particular social contexts after migration. Lan is right when she says that, instead of treating skills as a given asset contributing to human capital, we should try to understand what happens to the value of those skills. ${ }^{25}$ For example, Smith and Favell talk about how the skill level of migrants can degrade after they migrate to their destination countries because, in many ways, their various forms of capital cannot be properly converted in the new situations. ${ }^{26}$ However, in the examples of the migrant professionals from Macedonia discussed in this paper we also see the opposite process: some local cultural knowledge or skill from their countries of origin gains additional value for these migrants after they have relocated. Lan views English-language fluency as a kind of 'linguistic' capital, following Bourdieu's definition of 'linguistic capital' as one form of cultural capital that can exist in different manifestations in both the embodied and the institutionalised state. ${ }^{27}$ As mentioned above, her concept of 'flexible cultural capital conversion' to describe how Western migrants, given their linguistic habitus and privileged locations in the global geography of power, are able to convert their English-language capital into economic and social capital and status privilege, can be useful in this case, too.

The data produced for this research reveal one pattern that may contribute to the understanding of what happens to the value of a specific knowledge or skill in particular social contexts after migration: these migrant professionals mobilise some forms of their specific knowledge and experience in order to create individual or unique profiles in their work place.

${ }^{24}$ Jonathan V. Beaverstock, Transnational Elites in the City. British Highly-Skilled InterCompany Transferees in New York City's Financial District, Journal of Ethnic and Migration Studies 31, No. 2 (2005), 245-268.

${ }^{25}$ Lan, White Privilege, Language Capital and Cultural Ghettoisation.

${ }^{26}$ Michael Pete Smith / Adrian Favell, The Human Face of Global Mobility. International Highly Skilled Migration in Europe, North America and the Asia-Pacific, New Brunswick and London 2006.

${ }^{27}$ Lan, White Privilege, Language Capital and Cultural Ghettoisation; Pierre Bourdieu, The Forms of Capital, in: John G. Richardson, ed, Handbook of Theory and Research for the Sociology of Education, New York 1986, 241-258. 
One of the several stories that emerge from the interviews is that of Sonja (42), an economist and researcher who migrated to Germany seven years ago with her boyfriend and colleague. These are her words:

'At my workplace, they value innovation most. You need to invent a new methodology, a new research design, a new everything. So now I try to organize this unique project that nobody else can come up with, as it is linking my experience in Macedonia and the one in Germany. Back then, when I was still working in Skopje, we were using only one specific but very old methodology for our research, which nobody now uses in the world. However, my experience says that in fact that methodology was the best for this specific kind of project. So I want to make a project where I actually promote the old methodologies for some analyses that we do here. I can show them my results from Macedonia if they don't believe that that old-fashioned way is better. Maybe then I would have the opportunity to have my own bigger project to run ... That would be a great new challenge. You need to show that you can be a leader here and innovative, as I already said, and independent, and creative [...] That's what capitalism is, like it or not [...].'

The interviews also show patterns and ways in which migrant professionals link some aspects of their transnational identities to possible expected privileges or concessions. These allowances are nevertheless mediated and constrained by their access to specific ways of doing things in Macedonia that are not familiar to their colleagues in the workplaces they have moved to. For example, Sonja associates laziness with the 'south', and expects some leeway in some matters just because she is from the 'south'. Thus, she added to her statement that the only thing that her colleagues might not like is that she does not work very fast and she is often late with deadlines. To this, she added: 'But they know we from the south are always late, so I have the feeling that they have just accepted me like that $[\ldots] . .^{\prime}$

Such cultural essentialism functions as an access to preferential treatment for others too. Marija (36) is a social scientist who lives and works in a small university town in Bavaria. She is not married but she has a partner who is also a social scientist.

'It wasn't so easy at the beginning, but I was very lucky to work with a professor who knew how bad the higher education is in Macedonia. When we were interviewed about the $\mathrm{PhD}$ position, I was totally disappointed, as I thought everybody else [was] much more advanced then me. Then at the interview they asked me whether I know some methodologies, and I said no. I said I wanted to learn them, but they simply don't offer those courses in Macedonia [...]. I explained that we were very limited there in terms of access to knowledge and other resources, and that we even do not have any books on that. But it is true [...] they should not evaluate us with the same merit system as these German[s]. Look where they have studied, and look at our university there ...'

And she added: 
'But now it is fine. At the moment I am researching some things about education, and I am comparing Macedonia and Germany. It is quite tough, as there are also some important similarities. Comparisons are very important in our fields. Give them a comparison, and they give you money for the project. So everything I research has something do with Germany and the Balkan region [...].'

In the same way as Sonja and Maria, Arben (38), a psychiatrist who developed his specialisation in the hospital in Germany where he is still working, is able to convert some aspects of his status as a 'transnational expert' there into economic, social and symbolic capital. He invokes aspects of cultural essentialism to show his patients how it is different elsewhere:

'I think that most of my patients like that I am not German. They like hearing my stories about Macedonia. I also see it as part of the therapy to tell them examples from our cultures. People need to hear something different, examples from another world, as that is somehow putting their problems into perspective. When I tell them for example that we in Macedonia never go to a psychiatrist, they are amazed. Also many find it very interesting that we never talk about organic food [...]. And many ask me to tell them more and more stories. So I am glad to have all these many patients here that find Macedonian stories useful and fun [...].'

The data show that these migrant professionals are also active in global networks, activated principally in the contexts of their workplaces. However, in this widened general pattern of links, though they are embedded in global-local relations, they are excluded from the local networks in their places of origin, being more active in specific career-related networks. In his work on British expatriates in Singapore, Beaverstock also notices such patterns: he writes about the ways in which the migrants there are deeply embedded in global-local relations in their workplaces through interaction with local 'western educated/ experienced' Singaporeans. But they are disengaged from the local in the home and other household social spaces due to the invisibility of the local population in their interactions. ${ }^{28}$ Boris and Ivan are two examples of this.

Boris (45) is an engineer and works for a German IT company. He has been married since the time when he still resided in Macedonia, and he and his wife have two children. Before migrating, he worked in Skopje in the same branch of industry, while, at the same time, working on the PhD he has just completed at a German university. This is how he talks about his position as a professional sustaining relationships between his place of origin and his new environment in the context of a professional career:

'I have to be honest. Since I am here I know more about how this business is run in Macedonia. I am now trying to have my own project here, something GermanMacedonian; and I plan to include a few Macedonian companies. I tried also to

28 Jonathan V. Beaverstock, Transnational Elites in Global Cities. British Expatriates in Singapore's Financial District, Geoforum 33 (2002), 525-538. 
persuade one colleague from Skopje to run the project together [with me]. And if we are good and make some good profit, we could even enlarge the project and run it for years and years within my company here. We can make it a big thing, I am telling him. That is how it is here [...] if you have your own thing, something that is exclusively yours, like your own project that nobody else in the company can do in the same way, and if you bring some profit to the company at the same time, you can stay here forever. Nobody else speaks our languages here and nobody else knows the ways we do things in Macedonia and in the Balkan region as I. I invited him to join me in this project as I am not there anymore, I am losing my everyday local contacts, and I am so glad about that, as they take so much time that you can never get back [...]. And this project could be a nice base for the future [...]. Then you can take out a mortgage, buy something, enlarge the family [...].'

In the same way, Ivan (40), a medical doctor, talks about his position as a 'transnational' in the hospital where he works. He too is married to a woman from Macedonia whom he met four years ago when he returned to visit his family. She accompanied him to Germany and, since then, they have continued to live in the town where he got his first job in Germany seven years back.

'I don't have contacts with my former colleagues in Skopje that often. Sometimes they ask me about a particular case, and they want to know if we treat illnesses in different ways here. I am not really a social type, and I am not in contact with many people that I used to know there. I don't know what is happening in most of their lives. I guess it is my fault for not asking or e-mailing more frequently [...]. And if you ask me about work, I can say that in general I am in close contact with some institutes that have good databases, where they store data in better ways than other places, so I have some data to compare with our statistics here. That gives me a better overview of the whole system, so I am thinking that I should make a PhD out of it $[\ldots]$. Some historical analyses or so [...]. So yes, that is the best advantage of the networks I have there, and one day a great $\mathrm{PhD}$ may come out of it [...].'

The stories of these professionals from Macedonia who have settled in Germany show how they regard their transnational status as something that can be converted into social, economic, and cultural capital in terms of their career and how they mobilise their cross-border ties, networks and connections with their colleagues in Macedonia to achieve a better position in their German workplaces.

\section{The Rooted Others. Boundary-Work in Context}

Another pattern is visible in the data. Migrant professionals' mobilisation of transnational ties, networks and experiences into economic, social and symbolic capital serves them not only to win better positions or unique profiles at work, but also to secure more stable positions on the labour market-most often in the institution where they are currently working. Thus, they promote their status as 'transnational experts' to become, or remain, rooted in the places 
where they have settled. In this process, they mainly compare their position on the labour market with German colleagues at work or elsewhere, who have more straightforward, rooted, and linear careers (since they are in their own home country) but have no transnational experiences. Thus, in their narratives about how they perceive themselves as migrant professionals in Germany, their main boundary-work is not between themselves and other migrant professionals from Macedonia or elsewhere, and not even between themselves and less skilled migrants, as might be assumed. According to Lamont, it is likely that boundaries are primarily drawn in opposition to one group rather than to multiple groups, and this group consists of the 'privileged others' ${ }^{29}$ In this sense, the rooted co-workers the migrant professionals have as colleagues can be understood as their 'privileged others'.

The attempt to understand the ways these migrant professionals from Macedonia define their distinct identities as 'professional migrants in Germany' and how they differentiate between themselves and others takes us to the mentioned constructivist theories about identity-formation. According to these theories, social identities are not static or given, but are changing and ever-inthe-making; they are not pure, but hybrid and mixed. The constructivist approach to identity embodies the idea that identity and ethnicity are not what people 'have', but are products of boundary-work, which depends greatly on the meanings people give to these attributes. Thus, identities are based on the 'dichotomising' nature of the boundaries established, causing others to be identified as 'strangers' or 'members of another group'. Social identities, thus, always represent a dialectic relationship between internal and external definitions. The boundaries and the 'we/they' divides are products of social interaction, and, because of this, they are subject to change and modification with time. Social relations are maintained across such boundaries and they are based precisely on the demarcations these boundaries set, to provide dichotomised ethnic statuses. Boundaries are important to people, since they rely on being able to differentiate between themselves and others; boundaries signify the point at which something becomes 'something else', at which 'we' ends and 'they' begins. Thus, the crossing and the modification of boundaries have great significance for everyone. People construct boundaries by accepting common habits, practices, meanings, and modes of acting and they reject and even combat ways that are not theirs. Boundary-work and identity-formation are thus inseparable from one another and understanding what identity is entails an exact knowledge of what boundaries do.

29 Michele Lamont/Virag Molnar, The Study of Boundaries in Social Sciences, Annual Review of Sociology 28 (2002), 167-95. 
The research in this paper shows, above all, that identity and boundaries are not only constructed, but also bounded by the contexts in which they occur. ${ }^{30}$ Thus the migrant professionals cited compare their position with the more 'stable and rooted' professionals around them. Other studies have revealed similar patterns. Kefalas, for example, writes that the white working class in Chicago 'place' themselves in American society by denying their marginality and largely positioning themselves against poor blacks: 'Class-bound ideologies and boundaries make it difficult for garden dwellers to reconcile themselves to the existence of white teenage mothers, white homeless, white drug addicts, white gangbangers, white single mothers, and poor whites. ${ }^{31}$ Watters has shown too how Indian migrants in the USA build strategies of self-presentation while drawing boundaries in relation to African-Americans. ${ }^{32}$ DiTomaso writes how lower-class whites in the USA compare their position on the labour market with those of blacks; and Young Jr., to give another example, has researched the identity patterns of poor young black men and the ways they position themselves in society in relation to the social position of others. ${ }^{33}$ Lamont and Trevenot have analysed the research findings on cross-national boundary-making strategies to understand how national identities are defined in opposition to one another. By comparing the criteria of evaluation applied to environmentalism, art appreciation, racism, and other areas in France and the USA, they show that there are various yardsticks, such as market principles or particular kinds of aesthetics that are present in each nation and region but in varying proportions - differences that, the authors suggest, constitute the basis for diverging national identities. ${ }^{34}$ Moreover, as Lamont shows, these differences further serve as a basis for policy-making: the research done by Saguy, for example, reveals how the

\footnotetext{
30 Cf. Michele Lamont, Money, Morals, Manners. The Culture of the French and American Upper-middle Classes, Chicago 1992; Michele Lamont, The Dignity of Working Men. Morality and the Boundaries of Race, Class and Immigration, Cambridge MA 2000; Ann Swidler, Talk of Love. How Culture Matters, Chicago 2001.

${ }^{31}$ Maria Kefalas, Working-Class Heroes. Protecting Home, Community and Nation in a Chicago Neighbourhood, Berkeley and Los Angeles 2003, 155.

${ }^{32}$ Mary C. Waters, Black Identities. West Indian Immigrant Dreams and American Realities, Boston 1999.

${ }^{33}$ Nancy DiTomaso, Why Anti-Discrimination Policies Are Not Enough. The Legacies and Consequences of Affirmation Inclusion-for Whites, Presented at the 95th Annual Meeting of the American Sociological Association, Washington/DC, Anaheim/CA, 2000; Alford Jr. Young, The Minds of Black Men. Making Sense of Mobility, Opportunity and Future Life Chances, Princeton 2004.

${ }^{34}$ Lamont, Money, Morals, Manners; Lamont, The Dignity of Working Men; Michele Lamont / Laurent Trevenot, eds, Rethinking Comparative Cultural Sociology. Repertories of Evaluation in France and the United States, Cambridge/MA 2000.
} 
sexual harassment policy adopted in France is explicitly defined against what is viewed as American political correctness. ${ }^{35}$

To provide support for the argument just highlighted, I present more data from the interviews conducted with three of the five migrant professionals introduced previously: Marija, Arben and Boris. Marija explains how her aim is to create an academic profile that can provide her with a stable position in the place where she now works:

'I wrote a paper that was a bit too good for this German journal that is dealing with our Balkan region. But I thought that my name should become familiar to these scholars in Germany [who] write about our region. It is useful, I would say, to also invest in the local networks in academia .... So I submitted it, and they accepted it. And since then I feel like they know me more ... One colleague from Munich said that she read the paper and that they could invite me as a guest speaker there ... Great! It couldn't be better, I guess. If I get a job, I would gladly stay. But where to go? England? Fine, but you need different things in your CV for that. So it is better to focus on Germany and Bavaria, meet all the professors from my field and go to the colloquiums ... Last fall there were two conferences at the same time: one in Manchester and one here. And my boyfriend had wanted to go to Manchester for a long time-the football stuff, you know ... He insisted on going to Manchester, but I decided to go to the local [conference]. It is nice to build roots here, too. And it is better for the career, as they will see here that you are active in the networks, interested in what they do. It seems that everybody wants to be at Oxford or Harvard, but these more localized departments offer a better environment, [a] more familiar one, and that is exactly what I always wanted: to have better working conditions than in Skopje, but still to belong to one place ... Maybe one day I will move, but I should know where I am moving from, so I can say I came from there and here, I worked with them and them, I did this and that.'

In the narratives offered by Arben and Boris, is it is also noticeable how they mobilise their cross-border ties and networks to become, or to remain, rooted in the places where they are. They, too, try to articulate who they are in Germany in relation to colleagues who have more straightforward, rooted, and linear careers and lives.

'I see myself here, and only here. Privately, but also professionally that is best for me. As a psychiatrist, it is important for me to stay, as sometimes people go to the same psychiatrist for years or decades ... Also privately, I would love to stay here, as I think that way I would have less worries, less things to plan ... and when you move a lot, you spend half of your lifetime on planning. And you also have to start from the beginning all over again ... My German colleagues don't have that. But they have the advantage of being here in this town for a long time and they have built a huge reputation by now. You need a lot of time for a good reputation. And

35 Abigali C. Saguy, What Is Sexual Harassment? From Capitol Hill to the Sorbonne, Berkeley/CA 2003, quoted in Lamont/Trevenot, eds, Rethinking Comparative Cultural Sociology, 185. 
these local psychiatrists that have been here for decades have started their careers much earlier than me, and that makes a lot of difference. And they are in their home country, where everything is familiar and where the language is not a problem. They have more advantages just by staying at the same place. What could be better than being at home and at the same time being able to build a great career and have a family [in] that same place you call your home since you were born?'

Boris says that it takes a lot of courage to move to another country, and that he would not do it again:

'No, I wouldn't move anywhere and I truly hope that they won't relocate me at work. But the things at our company are very clear regarding that: if I improve my CV a little bit more, if I am always better and better in what I do, if I could just add a few more things in my CV, I will be in a safe place. They wouldn't be able to replace me easily $[\ldots] .$.

And he adds:

'I have a lot of experience in this company by now and I know exactly what it takes to be recognized here. For example, my colleague at the office, a half-German, halfAustrian, my age, very nice, has been working here for ages. His family is from here too, and he is building a house now too. These people are so lucky, I have to say that ... Everything one wants is here. And they don't even have to leave their country to have good salaries and proper jobs. That is why Germany is what it is, because its people want to stay here and contribute to this country, something that we in Macedonia will never have. They have families here, many job opportunities: they don't have to worry about their future at all. Hey! Who has that among us down there in Macedonia?! He [the German] never worries about work in the same way as us. He has his job here, he is very good in what he does, he is living a good life and he is just looking ahead ... And I am going back and forth non-stop. Skopje, then here, then again in Skopje. A project here, a project there ... Who knows, maybe I am just losing time? Many things can be learned from the people here. Just stay focused on one thing and look ahead, I would say [...].'

These interviews show these migrant professionals assessing their status as 'transnational experts' as something that can be converted into social, economic, and cultural capital to advance their careers, and mobilising their transnational ties, networks, and experiences not only to achieve a better position at work, but to secure more stable positions for themselves on the labour market-most often in the institution where they already work. What is more, the data show that in the narratives they give about who they are, as migrant professionals in Germany, their main boundary-work is between themselves and their German colleagues at work (or elsewhere), who have more straightforward, rooted and linear careers at hand in their own home country. 


\section{Final Thoughts}

The study of migrant professionals can contribute to the rethinking and reconceptualisation of mainstream methods and theories on migration in many significant ways. However, as Fechter and Walsh rightly point out, it is important not only to add 'privileged migrants and stir', but to understand the particular ways in which such studies may contribute to this undertaking. ${ }^{36}$

This article aims to contribute to the research on migration by analysing the ways in which professionals who have migrated from Macedonia to Germany relate to their status as 'transnationals' in the context of their careers. It shows that these migrant professionals regard their status as 'transnationals' as an asset that can be converted into social, economic, and cultural capital in their careers; and they mobilise their transnational ties, networks, and experiences in order to achieve better or 'unique' positions at work. Most importantly, it shows that, though these professionals promote their status as 'transnational experts', they aim to have careers that are rooted in one place, most often in the institutions where they are currently working. Furthermore, this pattern is also visible in their boundary-work processes: they compare their positions primarily with those German colleagues at work (or elsewhere) who have had more straightforward, rooted and linear careers but no transnational experience. Smith and Favell maintain that the skill levels of migrants degrade after they have settled in their destination countries because, abroad, the various forms of human capital they possess cannot be fully or properly converted for appropriate use. ${ }^{37}$ However, as this paper shows, this may not be entirely true for everybody: an understanding of the ways in which highly-skilled migrants adapt and use the value of their professional skills and networks can give us a clearer perspective on one specific type of migration.

\section{CORRESPONDING AUTHOR}

Ana Aceska, Humboldt-Universität zu Berlin, Kultur-, Sozial- und Bildungswissenschaftliche Fakultät, Institut für Sozialwissenschaften, Unter den Linden 6, 10099 Berlin. Email: aaceska@gmail.com

\footnotetext{
${ }^{36}$ Fechter / Walsh, Examining 'Expatriate' Continuities, 1198.

37 Smith / Favell, The Human Face of Global Mobility.
} 